\title{
Political Connections and Firm Performance: The Case of Hong Kong
}

\author{
Stan Hok-Wui Wong
}

\begin{abstract}
Business interests are overrepresented in Hong Kong's nominally democratic political institutions. Many in Hong Kong perceive this as evidence of the existence of "collusion between government and business," a phenomenon that has stirred public concerns in the city since its sovereignty transfer. Although anecdotal accounts abound, no systematic analysis has been conducted to evaluate the validity of this perception. In this article I use a rich firm-level dataset to offer the first systematic assessment of the effects of political connections on firm performance in Hong Kong. I define politically connected firms as firms that have stakeholders concurrently holding a seat on the Election Committee, a constitutional body that elects the city's chief executive. I found evidence, though not overwhelming, consistent with the "collusion" hypothesis: political connections do improve firm performance measured by return on equity and market-to-book ratio. The improvement is unlikely due to unobserved confounding factors such as firms' inherent ability. As for the origin of the political connections, the data show that a firm's economic power has little predictive value of its connections to the Election Committee. Rather, number of employees matters; firms that hire fewer workers were more likely to gain a seat on the 1997 Election Committee. This result may suggest that Beijing plays a more dominant role in the formation of political connections-that serve Beijing's co-optation needs rather than the interests of powerful firms that may have a desire to "capture" the state.
\end{abstract}

KeYwORDS: Hong Kong politics, Hong Kong economy, authoritarian politics, politically connected firms, crony capitalism

ince 2008, the legislature of Hong Kong has been investigating a former high-ranking government official's appointment in a leading real estate development firm. The case attracted the legislature's attention because the firm that hired the official reaped a handsome profit a few years prior from a deal handled by the former official. The prima 
facie evidence of the case is consistent with the popular belief that there exists some nefarious relationship between the government and major local business groups.

"Collusion between government and business" (guanshang goujie) has long been a major social concern in Hong Kong. ${ }^{1}$ Journalistic accounts abound about how the government offers particularistic benefits to big corporations. ${ }^{2}$ Yet, there has been no systematic empirical study on this subject. This article is intended to fill this void, examining, in particular, whether a firm's political connections can improve its business performance. The central assumption here is that firms' owners or directors have an incentive to intervene in politics if doing so can maximize their economic interests.

The firms being examined are those listed on the Hong Kong Stock Exchange (HKSE), whereas political connections are defined as membership in an important political institution (the Election Committee) concurrently held by the firms' shareholders or directors. I measure business performance along several dimensions, including return on equity, market-to-book ratio, and earnings per share. The empirical results show that political connections do improve firm performance with respect to return on equity and market-to-book ratio.

This article is intended to engage two audience groups. The first is those interested in Hong Kong politics. Many who study Hong Kong politics notice the overrepresentation of business interests in the city's political system. Hsin-chi Kuan $(1991,785)$ contends that the Basic Law, the city's miniconstitution, is "a pact between the Chinese government and the business and industrial elites in Hong Kong." Indeed, when Beijing organized the Basic Law Drafting Committee in the 1980s in anticipation of Hong Kong's sovereignty transfer, 70 percent of the members of the committee were business elites (Loh 2006, 33). The resulting law, as expected, tends to favor business interests. For instance, Article 115 of the Basic Law explicitly decrees that "the Hong Kong Special Administrative Region shall pursue the policy of free trade and safeguard the free movement of goods, intangible assets, and capital."

The political influences of the business are not confined to the making of the city's constitution. The business elite also plays a direct role in everyday politics. For example, in the year before the sovereignty transfer, Beijing set up a Preparatory Committee (PC) to deal with issues related to Hong Kong's political transition, including the establishment of the first Election Committee (EC), which elected the city's first posthandover chief executive. ${ }^{3}$ Of the 94 Hong Kong dele- 
gates to the 150 -member PC, more than 50 owned or worked for big corporations (So 1999, 220). Two-thirds of the 400 members of the first Election Committee were affiliated with mainland political institutions such as the National People's Congress (NPC) and various provincial people's congresses (Pepper 2000, 67). As expected, big businesses were overrepresented on the EC. Businesspeople occupied more than half of the seats (So 1999, 221). In addition, Hong Kong's legislature (known as the LegCo) currently has half of the total seats elected from functional constituencies, and some functional constituencies have only corporate electors ( $\mathrm{Li} 2007,25)$. In sum, suffice it to say, business interests have been an important source of influence on the city's constitution, the executive branch, and the legislature since the handover, if not earlier.

Despite their insightful observations, the studies cited offer only descriptive analysis of the government-business relationship in Hong Kong. The primary objective of this article is to provide a systematic empirical study to investigate the causal mechanism embedded in this relationship.

In addition to contributing to the literature of Hong Kong politics, this study is also intended to speak to a more general literature on politically connected firms. The economic effects of political connections have attracted increasing scholarly attention in recent years. Raymond Fisman (2001) estimates the impact of rumors regarding the health of former dictator Suharto on firms connected to him. Anup Agrawal and Charles Knoeber (2001) find that directors with political experience are more prevalent in firms where sales to government are greater. Using data from Malaysia during the Asian financial crisis, Simon Johnson and Todd Mitton (2003) find that firms with political connections suffer more when a macroeconomic shock reduces the government's ability to provide subsidies and benefit more when capital controls are imposed that allow the government to increase the level of subsidies. Asim Khwaja and Atif Mian (2005) use firm data from Pakistan to show that state-owned banks dole out substantially more loans to politically connected firms. Mara Faccio (2006) examines the effects of political connections on firms' performance with a sample of forty-two countries. She finds that political connections distort the allocation of investment funds by doling out benefits to less competitive firms. Another study (Fan, Wong, and Zhang 2007) shows that firms with politically connected CEOs underperform those without. Hongbin $\mathrm{Li}$ and colleagues (2007) use Chinese twin data to show that the economic returns to Communist Party membership disappears once individuals' 
ability and family background are controlled. However, Thomas Ferguson and Hans-Joachim Voth (2008) find evidence that German firms associated with the Nazi movement experienced substantially higher returns than politically unconnected ones. Others (Goldman, Rocholl, and So 2009) show that the announcement of the nomination of a politically connected individual to a company's board of directors in the United States would lead to a positive stock return.

This article is an interesting addition to the study of politically connected firms for three reasons. The first is that Hong Kong has long been a poster child for market economy. As of 2010, Hong Kong has been ranked by the Heritage Foundation as the freest economy in the world for sixteen consecutive years. Because the forces of supply and demand, rather than politics, are expected to govern market outcomes in Hong Kong, the relationship between political connections and firm performance can be put to a more severe test. The second reason is that the Hong Kong government has been widely perceived to be efficient and clean. Transparency International has consistently ranked Hong Kong as one of the least corrupt countries for as long as its Corruption Perceptions Index has been available. ${ }^{4}$ As Faccio (2006) shows, political connections are more widespread in countries that are corrupt than in those that are less so, in part because political connections are more economically profitable in corrupt countries. For this reason, political connections should be something of a rarity in Hong Kong, or they should bear insignificant economic values. If we do find significant values in this least likely case, then it would imply that political connections as a channel for rent seeking is far from insignificant.

Finally, an advantage of studying Hong Kong is that many important political and economic data are publicly available, and the rich data allow one to tease out the causal relationship more easily. In the literature on politically connected firms, many use political connections to explain economic outcomes. The central challenge confronting the extant literature is the threat of omitted variables. For instance, we may observe that firms with political connections have better firm performance than firms without. It is possible that political connections give those firms more rent-seeking advantages, which lead to their better business performance. Equally possible is, however, that competent firms achieve better business performance, and these firms are more likely to build political connections. Because data for Hong Kong are available for before and after the sovereignty transfer, the method of differences-in-differences to control for unobserved, contemporaneous confounding variables can be used. 
This article is also closely related to studies of corruption (see, for example, Shleifer and Vishny 1993, 2002). Unlike corruption, political connections as defined in this article are publicly known and legal. I argue that the studies of political connections are no less important than the studies of corruption. If some economic agents dare to improve their business interests through corruption, which is defined by Daniel Treisman (2000) as "misuse of public office for private gains," we should expect to see a lot more economic agents attempting to use public office in less contemptible ways for private gains.

In presenting my study, I begin by providing background information on the government-business relationship in Hong Kong. I then discuss the hypotheses to be tested, describe the dataset, present the empirical results, and conclude with a discussion of my findings.

\section{Background}

The Qing court ceded Hong Kong to Britain in the mid-nineteenth century after its defeat in the Opium Wars. Under British colonial rule, Hong Kong achieved an impressive economic development, especially during the postwar era. Hong Kong's gross domestic product (GDP) per capita increased tenfold from US $\$ 3,000$ to US $\$ 30,000$ between 1960 and 2004. Along with this rapid economic growth, Hong Kong gradually transformed its economy from one based on manufacturing to one based on services. Currently, one-third of Hong Kong's GDP comes from finance and commerce. ${ }^{5}$

While Hong Kong witnessed an impressive economic development in the postwar era, the People's Republic of China (PRC) experienced a series of tragic economic and political events, such as the Chinese Civil War, the Great Chinese Famine, and the Cultural Revolution. Many mainland Chinese fled to Hong Kong for refuge.

China and the United Kingdom began discussing the Hong Kong sovereignty issue in the early 1980s. In 1984, they signed the SinoBritish Joint Declaration, agreeing to transfer the sovereignty of Hong Kong to the PRC in 1997. As the memory of persecution by the Communist Party was still fresh in the mind of many Hong Kong people, who were once immigrants escaping from China's Communist rule, a wave of emigration broke out even before the declaration was signed.

To strengthen the confidence of the people of Hong Kong in the city's future, Beijing proposed the "one country, two systems" formula, 
under which Hong Kong could enjoy a high degree of autonomy after the sovereignty handover. In addition, Beijing promised that the lifestyle of Hong Kong would remain unchanged for literally fifty years. ${ }^{6}$

The vision promised by the "one country, two systems" formula was mainly about economic prosperity. Beijing seemed less interested in using political liberty to strengthen the confidence of Hong Kong residents. For one thing, it did not lay down any clear blueprint for democratizing Hong Kong's political system. In fact, as Ian Scott (2000, 31) points out, the Chinese government in the 1980s found the existing British system of administration, characterized by an authoritative, if not autocratic, governor assisted by an effective and professional civil service system, to be a viable model for the posthandover Hong Kong government.

The Chinese government's brutal crackdown on the Tiananmen prodemocracy movement in 1989 shocked Hong Kong. As fear of the Chinese government escalated among the people of Hong Kong, the public support for installing democratic institutions as a check on Beijing soared. Beijing now found it harder to ignore Hong Kong's demand for greater political freedom. In fact, it might also be in Beijing's interests to address that demand, because by doing so, together with successfully implementing the "one country, two systems" formula, Beijing could polish its international image - an image that had been tarnished by its 1989 brutal crackdown. In addition, the Kuomintang government on Taiwan introduced radical democratic reforms in the early 1990s. If Beijing wanted to use Hong Kong's "one country, two systems" formula to lure Taiwan into reunification talks, ${ }^{7}$ it should respond to Taiwan's democratization with some positive development in Hong Kong's political liberalization process.

Beijing therefore set up various quasi-democratic institutions in Hong Kong in hopes of alleviating the public's fear of the sovereignty transfer. Chief among them was the Election Committee, a constitutional body that had one political function: electing the city's chief executive. ${ }^{8}$ Since political connections examined in this article refer to the membership of the Election Committee, it is necessary to describe this political institution in detail.

The first Election Committee consisted of 400 Hong Kong citizens designated by the PRC's National People's Congress. These 400 members represented four broadly defined social quarters of the city: the industrial, commercial, and financial constituency; the professional constituency; the labor, grassroots, and religious constituency; and the 
political constituency, which includes representatives to various local and national political institutions such as the NPC. Because all the members of the first Election Committee were handpicked by Beijing, Beijing effectively controlled the entire electoral process.

With the term of the first chief executive due to expire, a new Election Committee was formed in 2000 to pick the city's next political leader. The second Election Committee differed from the first in two important ways: its membership expanded to 800 , and the members were no longer chosen directly by Beijing. The 800 members were elected by the constituencies of the four privileged social groups mentioned, which were further divided into some forty subsectors (see Table 1). Despite its seemingly representative outlook, the election of the second Election Committee was far from democratic. First, more than 300 members won their seats in uncontested elections. ${ }^{9}$ Second, the majority of the city's population did not belong to the EC constituency. Pang-kwong Li $(2007,25)$ points out that the electorate of the entire Election Committee formed in 2000 consisted of 163,445 people, excluding the geographical constituency of the LegCo subsector. ${ }^{10}$ This electorate accounted for merely 2.4 percent of the Hong Kong population. These institutional features allowed Beijing to continue to influence the electoral outcomes. In fact, some (e.g., Holliday, Ma, and Yep 2004, 260) even contend that the chief executive election was a "de facto appointment from Beijing."

That Beijing plays a dominant role in the formation of the Election Committee has a significant political implication; the elected members are not necessarily representing the interests of the sector that elects them, because these members' electoral success depends more on Beijing's blessing. ${ }^{11}$ For this reason, if a firm has a shareholder or a director elected to the Election Committee, it is reasonable to expect that that person would represent the interests of the firm rather than the interests of the sector to which the firm belongs.

As was mentioned, the Election Committee, like other quasidemocratic facades set up by Beijing in Hong Kong, was overrepresented by business interests. The reason is simple. The business elite in Hong Kong was desperate to build a good relationship with Beijing, since members of that elite all eyed the enormous market of the PRC. Scott $(2000,31)$ observes that during the period of transition, there was a massive wave of defection of most big businesses from the British camp to Beijing's. To build a good relationship with Beijing, these businesspeople needed to show their loyalty. Beijing provided them an opportunity to do so: by sitting on the Election Committee and electing whomever 


\section{Table 1 Sectors and Subsectors of the Election Committee in 2000}

\begin{tabular}{|c|c|}
\hline Sector and Subsector & Seats \\
\hline \multicolumn{2}{|l|}{ Industrial, commercial, financial } \\
\hline Catering & 11 \\
\hline Commercial (first) & 12 \\
\hline Commercial (second) & 12 \\
\hline Employers' Federation of Hong Kong & 11 \\
\hline Finance & 12 \\
\hline Financial services & 12 \\
\hline Hong Kong Chinese Enterprises Association & 11 \\
\hline Hotel & 11 \\
\hline Import and export & 12 \\
\hline Industrial (first) & 12 \\
\hline Industrial (second) & 12 \\
\hline Insurance & 12 \\
\hline Real estate and construction & 12 \\
\hline Textiles and garment & 12 \\
\hline Tourism & 12 \\
\hline Transport & 12 \\
\hline Wholesale and retail & 12 \\
\hline \multicolumn{2}{|l|}{ Labor, social services, religious, others } \\
\hline Agriculture and fisheries & 40 \\
\hline Culture sub-subsector & 10 \\
\hline Labor & 40 \\
\hline Publication & 10 \\
\hline Chinese Muslim Cultural and Fraternal Association & 6 \\
\hline Hong Kong Christian Council & 7 \\
\hline The Confucian Academy & 7 \\
\hline The Hong Kong Taoist Association & 6 \\
\hline Catholic Diocese of Hong Kong & 7 \\
\hline The Hong Kong Buddhist Association & 7 \\
\hline Social welfare & 40 \\
\hline Sports & 10 \\
\hline Performing arts & 10 \\
\hline \multicolumn{2}{|l|}{ Political offices } \\
\hline СРPCC & 41 \\
\hline Heung Yee Kuk & 21 \\
\hline Hong Kong and Kowloon District Councils & 21 \\
\hline Legislator & 60 \\
\hline New Territories District Councils & 21 \\
\hline NPC Member & 36 \\
\hline \multicolumn{2}{|l|}{ Professions } \\
\hline Accountancy & 20 \\
\hline Architectural, surveying, and planning & 20 \\
\hline Chinese medicine & 20 \\
\hline Education & 20 \\
\hline Engineering & 20 \\
\hline Health services & 20 \\
\hline Higher education & 20 \\
\hline Information technology & 20 \\
\hline Legal & 20 \\
\hline Medical & 20 \\
\hline
\end{tabular}

Note: There is no information on the subsectors of the first Election Committee, which was formed in 1996. 
Beijing wanted. In sum, the membership of the Election Committee was characterized by an exchange of economic rent and political loyalty.

\section{Hypotheses}

The key question that I aim to answer in this article is whether collusion between government and business exists in Hong Kong. The term collusion, as is commonly understood in Hong Kong and elsewhere, carries a negative connotation. It involves secret and wrongful exchanges between people. Because such exchanges are supposedly done in secrecy, the act of collusion is hardly observable. For this reason, we can only use indirect methods to evaluate whether collusion exists or not. For instance, we can check if the parties involved in the said collusion benefit from each other's actions. The problem is that the benefits resulting from collusion are often unobservable. Consider the case of Hong Kong. Perhaps the best way to prove if collusion between government and business exists is to check Election Committee members' bank accounts to see if government authorities deposit huge sums of money in them after the election of the chief executive. Obviously, such information is never available.

In this discussion, I use a more indirect way to assess the collusion hypothesis. I examine the performance of firms owned or managed by members of the Election Committee, in the belief that if the collusion hypothesis is true, we should expect to see that firms improve their business performance after becoming politically connected. Relying on this indirect approach can be considered a compromise I have to make for not being able to gain access to more direct information (such as members' bank accounts). Nevertheless, I argue that this is a viable strategy to evaluate the collusion hypothesis, for the following reason. The rule of law and media freedom remained largely robust in Hong Kong after the sovereignty transfer. It is unlikely or unnecessary for Beijing to use overtly contemptible means, such as direct money deposits, to reward its political supporters. Beijing can reward its political supporters by other means, including relaxing regulations, granting licenses, and restricting competitors' entry. The benefit resulting from these favorable government policies should therefore be reflected in the business performance of the political supporters' firms. ${ }^{12}$

A caveat is in order. The collusion hypothesis does not assume that the business elite is necessarily passive, in the sense that it offers Beijing political support and waits for the latter's bounty. Sometimes the business 
elite can be assertive. For example, Leo Goodstadt $(2005,136)$ points out that when Tung Chee-hwa, the first chief executive, introduced his ambitious public housing plan in 1997, Hong Kong's major property magnates, whose economic interests were hurt by Tung's plan, directly complained to Beijing, in hopes of using Beijing's pressure to force Tung to withdraw the plan. Tung later did give up his plan, though it remains unclear to what extent his decision was due to the influence of the big developers. ${ }^{13}$

We will now examine four hypotheses related to the collusion claim.

\section{H1: Political connections improve firm performance.}

To discover the effects of political connections on politically connected firms, we cannot just compare the connected firms' business performance before and after establishing the connections because the difference may be generated by unobserved and concurrent confounding factors. This is especially relevant in the context of Hong Kong, given that the city underwent a severe economic downturn immediately after the handover as a result of the Asian financial crisis. In addition, this approach is unable to deal with the threat of reverse causality; a statistically significant correlation between the two may reflect that firms with good performance are likely to build political connections, rather than political connections improving firm performance.

To tackle unobserved confounding factors and the reverse causality problem, I use a differences-in-differences estimation strategy. The advantage of this approach is that it uses the intertemporal change within and across groups (politically connected and unconnected firms) to control for any unobserved group characteristics that may be endogenously determined by the dependent variable.

Despite its advantage, the differences-in-differences estimation strategy has its limitations. Even if the estimation results show an improvement in business performance after firms acquire political connections, which is consistent with the prediction of the collusion hypothesis, such results cannot be considered sufficient evidence to prove the existence of collusion. The reason is that they may merely reflect that political connections come with a positive signaling effect; that is, having successfully built political connections may reveal a firm's overall ability. Such signals can update investors' belief about the firm and hence may leave positive impacts on the firm's subsequent performance.

We can, however, take a closer look at the within-group variation of politically connected firms to estimate the importance of the signal- 
ing effect. If the signaling effect drives all the results (if any) identified in the baseline regressions, we should expect to see an absence of within-group variation with respect to the effects of political connections because all politically connected firms should benefit from the signaling effect bestowed by their political ties. Operationally, because political connections examined here refer to the membership of the Election Committee and because the Election Committee consists of different constituencies, we have the second hypothesis:

H2: The effects of political connections on firm performance do not vary by firms' political constituencies.

Regardless of whether $\mathrm{H} 1$ and $\mathrm{H} 2$ are empirically supported, it would be interesting to ask why some firms were able to build political connections. In the literature on politically connected firms, there is no consensus on the origin of firms' political connections. Some argue that competent firms tend to build political connections more easily (Ferguson and Voth 2008; Goldman, Rocholl, and So 2009). This view is in line with the "state capture" argument, which suggests that government regulations are sought by firms in order to restrain competition or entry (Posner 1974; Stigler 1971). Others contend that firms seek to build political connections precisely because they run into trouble, and political connections help them get bailouts from the government (Faccio 2006). Both claims have empirical support in previous studies.

\section{H3: Competent firms have a higher likelihood of forming politi- cal connections.}

H4: Incompetent firms have a higher likelihood of forming political connections.

It is important to note that both views are concerned with the demand side of the political connections. What about the supply side? The reason why the supply side is omitted from the theories is probably because economists, who proposed these theories, often take politics as a given. Government, which supplies the political connections, is often assumed to react spontaneously to lobbies. This assumption is perhaps reasonable in a democracy, in which the government must face reelection pressure from time to time. In authoritarian regimes, where the pressure of reelection is absent, political leaders often respond to lobbies selectively - that is, they supply political connections based on 
their own political needs rather than at the request of economic agents. In fact, how dictators use private benefits or public offices to co-opt the socioeconomic elite in order to achieve their political goals has been widely studied in the literature of authoritarian politics (Geddes 1999; Gandhi and Przeworski 2007; Magaloni 2008). Ambrose King (1973, 7) also observes that the colonial government of Hong Kong had started to recruit Chinese business elites into various administrative institutions in the mid-1960s in response to growing tension between the government and its subjects.

The extant literature of authoritarian politics is mute about what kind of firms are more likely to be co-opted by authoritarian regimes. In the case of Hong Kong's transition, Beijing created various nominally democratic institutions in hopes of advancing its political agendas, such as alleviating Hong Kong's confidence crisis and luring Taiwan into reunification talks. With the firm data from Hong Kong, we may perhaps be able to generate new insights into the choice of cooptation targets by authoritarian regimes.

\section{Data}

Two sets of data are required to test the various hypotheses proposed in the previous section. One is statistics on firm performance. The quarterly financial data about firms' performance come from Datastream. ${ }^{14}$

Another set of required data is information on political connections. In particular, I needed to find out who holds various public offices. To this end, I primarily examined Election Committee seats in 1997 and in 2000. The reason for choosing this political institution as a target of investigation is twofold. First, as was mentioned, many identify this committee as an important channel for distributing spoils (Yep 2007, 257). Second, this committee is not a regular government agency involved in day-to-day policymaking. It has only one function: electing the city's chief executive. It is widely believed that the electoral outcome is predetermined by Beijing. Therefore, the Election Committee is largely considered to be merely a rubber stamp operation. Since most members hold little substantive policymaking power, the benefits of their political connections should come mostly from their political title. This setup puts the hypotheses to a more severe test. If we find that such shallow political connections are associated with significant economic benefits, we have reason to believe that deeper political connections would yield even greater economic gains. 
Although here I define political connections as having a seat on the Election Committee, this is not to say that there is no other form of political connections. For instance, there were eighty-nine red-chip firms ${ }^{15}$ listed on the HKSE as of 2008. Few would doubt these firms' political connections. Yet these are not local firms, and their relationship with Beijing is likely to be very different from that of local firms that joined the Election Committee. In other words, the political process through which the red-chip firms' economic rent, if any, is realized should be different from that experienced by the politically connected local firms. Admittedly, the political connections of these redchip firms are an interesting subject to study. Owing to the limited scope of this article, however, these connections are not considered here.

The membership of the Election Committee is public information and can be downloaded from the official website of the Hong Kong government's Electoral Affairs Commission. ${ }^{16}$

The assumption is that a firm can be connected politically through (1) its shareholders and/or (2) its managing directors. The detail of finding political connections is discussed in the following paragraphs.

\section{Connections Through Shareholders}

The HKSE maintains an online database, HKExnews, that allows the public to search for information on listed companies, including the names of substantial shareholders. A substantial shareholder is defined as an individual entity that owns at least 5 percent of a company's shares. The advantage of this database is that it supports searching by time frame. This is important because the substantial shareholders of a company may vary from year to year. With this database, I could accurately identify listed companies' substantial shareholders for each year. ${ }^{17}$

A disadvantage of this database is that its search by time frame function allows us to find data only after 2002. For tests related to earlier periods, I used a dataset that I compiled from the Hoenig Guide to the Companies of Hong Kong for 1998 and 2000, which contains information on substantial shareholders and directors of firms listed on the HKSE.

With the list of EC members and the list of companies' shareholders, the next step was matching up the two lists. Specifically, I needed to find how many shareholders, if any, serve in the EC for each company. The process is straightforward, but it involved two challenges. 
One was that cross-holdings are common among Hong Kong-listed firms; that is, one listed firm is another listed firm's substantial shareholder. ${ }^{18}$ As such, I had to take an extra step to "unpack" those listed substantial shareholders in order to discover who is really in charge. The second challenge was that the data contain thousands of individuals, and some of them may share exactly the same names. ${ }^{19}$ I crosschecked all the names of politically connected individuals to make sure that the names refer to the same people on the Election Committee.

\section{Connections Through Directors}

Substantial shareholders of a company are probably not the only stakeholders who would like to use their political connections, if any, to secure economic benefits. Directors of a company may also have such an incentive, since they may receive more bonuses or higher returns on their options when the firm's performance improves as a result of the political connections.

An additional reason why directors also matter is that sometimes a substantial shareholder of a company does not directly own the company's stock. Rather, they own it through a company or a family foundation. It is common knowledge in Hong Kong that Ronnie Chan, an EC member, is the person in charge of Hang Lung Group Limited (Stock Code: HK00010). He, however, is not a substantial shareholder of the company, whose leading owner is one of his family members. This example suggests that relying solely on substantial shareholders as a channel of political connections is likely to underestimate their actual pervasiveness.

The public can search the HKSE online database for the names of the directors of listed firms, given that the directors have disclosed their interests. Hong Kong's Securities and Futures Commission, a government agency that regulates the HKSE, stipulates that as long as a director owns company shares, regardless of the percentage, that person is obliged to disclose his or her shares at each stock transaction. ${ }^{20}$ Note that some directors do not own a listed firm's shares directly under their names. They own the shares of a company that in turn is a substantial shareholder of the listed firm. Under the regulation, such directors are still obliged to declare their interests.

The inclusion of directors in the search helps identify most political connections in a listed company. But still there may be cases where political connections remain unidentified given the search criteria. This is when a director holds absolutely zero shares of the company. The 
current law does not require such a director to declare interests. As a result, if an EC member is a listed firm's director but owns no share of the firm, my search method is unable to identify the firm's political connection established through this director. Such cases should be unusual, though, as few directors have absolutely zero stock interests in the company that they are managing.

\section{Data Description}

Of the 800 members on the 2000 Election Committee, 128 are affiliated with one or more listed companies; that is, they are either substantial shareholders of a listed company or its directors. Figure 1 shows the distribution of firm-affiliated EC members by subsector.

As expected, commercial subsectors tend to have more company directors and major shareholders. What is interesting is that the top

\section{Figure 1 Distribution of Firm Affiliations by Subsectors of} 2000 Election Committee

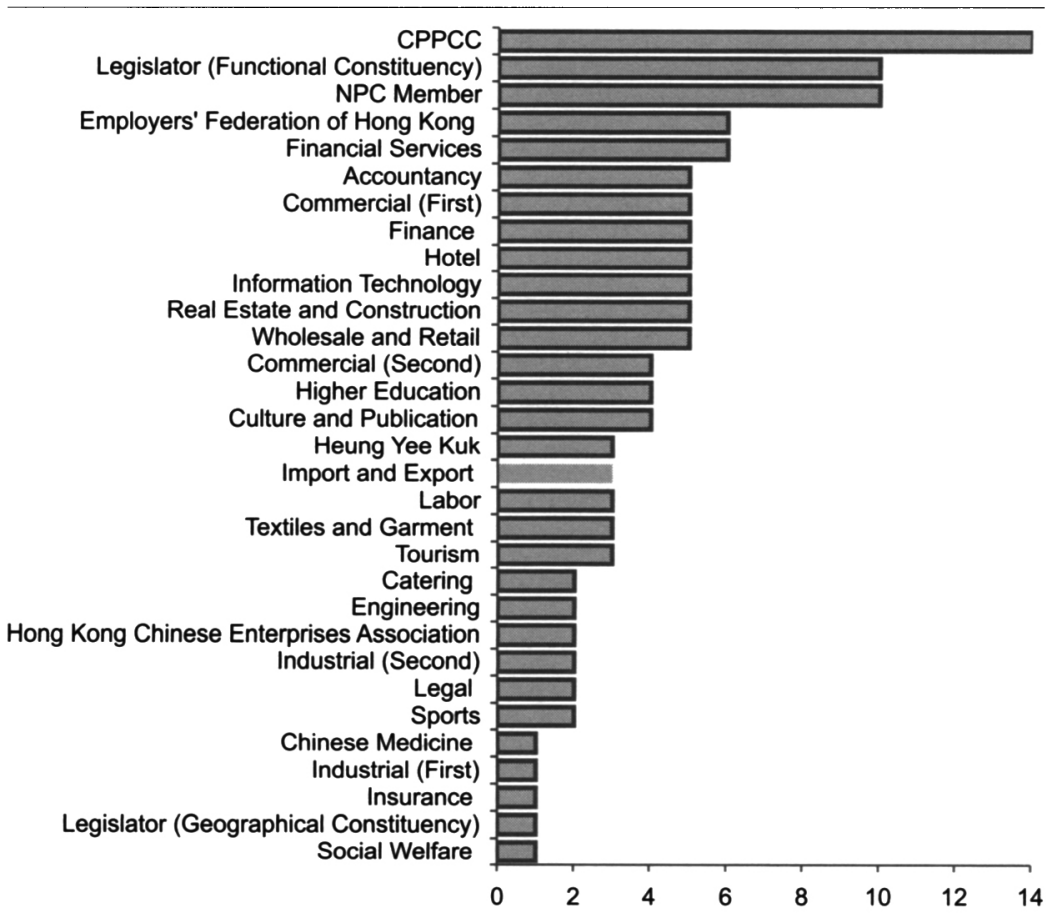

Number of firm-affiliated EC members 
three firm-affiliated subsectors are not from the industry subsector but from the political subsector. Among the delegates to the Chinese People's Political Consultative Conference (CPPCC), there are fourteen company directors or major shareholders. Members of the National People's Congress and legislators elected from the functional constituency have ten directors or substantial shareholders each. This pattern, however, should not be interpreted as evidence that political interests outweighed economic ones. The fact that political offices represent the top three is because Beijing had used various political offices to co-opt some economic elites long before the formation of the Election Committee. ${ }^{21}$

Now we change our perspective by examining firms that have political connections. Table 2 shows some trends of politically connected firms between 2003 and 2008. The general trend is that politically connected firms and individuals increased during that period. The increase reflects two concurrent events. One is that the Election Committee recruited more economic elites, and the other is that more firms were listed on the HKSE. Table 3 summarizes the basic statistics of listed firms in Hong Kong by their political connections.

It is not surprising that there are more politically unconnected firms than politically connected ones. After all, the Election Committee has only 800 seats, and only a portion of them is reserved for the business sector. Having a seat on the EC can be considered a privilege. What is interesting is that this privilege is shared by quite a few firms.

\section{Table 2 Trends of Political Connections}

\begin{tabular}{lccccc}
\hline & $\begin{array}{c}\text { Number of } \\
\text { Politically } \\
\text { Connected } \\
\text { Shareholders }\end{array}$ & $\begin{array}{c}\text { Number of } \\
\text { Politically } \\
\text { Connected } \\
\text { Year }\end{array}$ & $\begin{array}{c}\text { Number of } \\
\text { Firms with } \\
\text { Politically } \\
\text { Connected } \\
\text { Shareholders }\end{array}$ & $\begin{array}{c}\text { Number of } \\
\text { Firms with } \\
\text { Politically } \\
\text { Connected } \\
\text { Directors }\end{array}$ & $\begin{array}{c}\text { Number of } \\
\text { Listed Firms }\end{array}$ \\
\hline 2003 & 156 & 103 & 71 & 75 & 864 \\
2004 & 171 & 132 & 74 & 97 & 898 \\
2005 & 185 & 143 & 77 & 107 & 919 \\
2006 & 180 & 150 & 87 & 111 & 969 \\
2007 & 181 & 166 & 92 & 129 & 1,047 \\
2008 & 173 & 171 & 85 & & 1,093 \\
\hline
\end{tabular}

Sources: Datastream; Electoral Affairs Commission, Hong Kong.

Notes: The unit of observation is the firm. A firm is considered politically connected if it has at least one shareholder or director serving on the Election Committee, which elects the chief executive of Hong Kong. The observation period is between the first quarter of 2003 and the last quarter of 2008 . The same politically connected individual can be a substantial shareholder (director) in multiple companies. 


\begin{tabular}{lcccc}
\hline & & \multicolumn{2}{c}{ Politically Connected Firms } & \\
\cline { 3 - 4 } & & $\begin{array}{c}\text { Connected } \\
\text { Through } \\
\text { Shareholders }\end{array}$ & $\begin{array}{c}\text { Connected } \\
\text { Through } \\
\text { Directors }\end{array}$ & $\begin{array}{c}\text { Politically } \\
\text { Unconnected } \\
\text { Firms }\end{array}$ \\
\hline Market value (million HK\$) & Average & $25,160.15$ & $12,094.59$ & $4,215.41$ \\
& & $(153,579.1)$ & $(53,470.49)$ & $(22,797.71)$ \\
Market share & Average & 2.41 & 1.38 & 0.8 \\
Total assets (million HK\$) & Average & $(9.84)$ & $(4.69)$ & $(3.67)$ \\
Employees & & $(860)$ & 32.6 & 5.9 \\
& Average & $6,557.29$ & $(532)$ & $(37.9)$ \\
& & $(26,905.91)$ & $(138,746.8$ & $3,379.75$ \\
& & & & $(12,507.1)$ \\
\hline
\end{tabular}

Sources: Datastream; Electoral Affairs Commission, Hong Kong.

Notes: A firm is considered politically connected if it has at least one shareholder or director serving on the Election Committee, which elects the chief executive of Hong Kong. The observation period is between the first quarter of 2003 and the last quarter of 2008. Standard deviations are in parentheses.

About one-fifth of the listed firms are politically connected through either their directors or shareholders.

There are more connections through directors than through shareholders. This is due in part to the fact that many politically connected shareholders for various reasons hold the company's shares through a family foundation or a separate company. Consequently, we cannot track them down by shareholders' connections. However, because these people are the company's major stakeholders, who often assume senior management positions, we can spot them by examining companies' list of directors.

In general, these recent data of firms (between 2003 and 2008) show that politically connected firms have higher average market values, control larger market shares, command more assets, and employ more workers than their politically unconnected counterparts. This is especially true when it comes to connections through shareholders. For example, the average market value of firms politically connected through directors (HK\$12,094 million) is almost three times higher than that of politically unconnected firms (HK\$4,215 million). With respect to market value, firms connected through directors are on average only half the size of firms connected through shareholders (HK\$25,160 million).

Finally, note that cross-holding is common in Hong Kong. Sometimes the same politically connected individual owns more than one listed firm. 


\section{Results}

Political Connections and Firm Performance: Differences-in-Differences

The dependent variable is firm performance. I use three financial quantities commonly used in the literature to measure firm performance: ${ }^{22}$ return on equity (ROE), market-to-book ratio (MTB), and earnings per share (EPS). ROE reflects a company's profitability. It can be interpreted as the amount of profits to be created by each dollar invested. Presumably, the higher the ROE, the better the firm's performance.

MTB is a ratio of the market value of equity to the book value of equity. Eugene Fama and Kenneth French (1995) show that market-tobook ratio (or book-to-market ratio in their study) is associated with long-term differences in firms' profitability. In particular, firms with a high MTB ratio tend to be more profitable.

EPS represents the earnings for the fiscal year for listed companies. Earnings refer to profit after tax, minority interest, and preferred dividends. As in ROE, the higher the EPS, the better the firm's performance.

The panel nature of the data allows me to use the least squares dummy variable (LSDV) approach to test $\mathrm{H} 1$ and $\mathrm{H} 2 .{ }^{23}$ Year, quarter, industry, and firm-level fixed effects are included to control idiosyncratic shocks specific to a year, a quarter, an industry, or a firm. I also include a set of covariates in the regressions to control for firms' characteristics that may affect firm performance. These covariates are market value, market share, employees-to-assets ratio, number of employees, HSI constituent dummy, and log Hang Seng Index.

Using the Hoenig Guide to the Companies of Hong Kong 1998, I collected the names of directors and shareholders of firms listed on the HKSE in 1997. Then I uncovered political connections by matching the names of companies' directors and shareholders against the names of the Election Committee members.

To tackle unobserved concurrent factors and the reverse causality problem, I use the differences-in-differences estimation strategy. To use this approach, we need to identify a time point, based on which we measure the change within and across groups over time. An appropriate reference point would be 1997, the year after the NPC created the first Election Committee for the first posttransition Hong Kong government. ${ }^{24}$ I compare firms' performance four years before and after the formation of the Election Committee. The sample, therefore, is bounded 
between 1993 and 2000, inclusive. The full regression specification is as follows:

$$
\omega_{\text {fkyq }}=\alpha+\mathrm{EC}_{\mathrm{f}}+\mathrm{D}_{1997}+\mathrm{D}_{1997} \times \mathrm{EC}_{\mathrm{f}}+\boldsymbol{\theta}_{\mathrm{fkyq}}^{\prime} \beta+\eta_{\mathrm{f}}+\zeta_{\mathrm{k}}+\gamma_{\mathrm{y}}+\delta_{\mathrm{q}}+\varepsilon_{\mathrm{fkyq}},
$$

where $f, k, y$, and $q$ stand for firm, industry, year, and quarter, respectively. The dependent variable, $\omega_{f k y q}$, refers to return on equity, marketto-book ratio, and earnings per share, depending on the specification, of firm $f$ of industry $k$ in the $q$ quarter of year $y ; \alpha$ is a constant. $E C_{f}$ is a dummy variable that is assigned a value of " 1 " if firm $f$ has one or more shareholders/directors serving in the EC in 1997 and "0" otherwise. $D_{1997}$ is an indicator function for the year 1997 and after. $D_{1997} \times$ $E C_{f}$ is an interaction term between $E C_{f}$ and $D_{1997} \boldsymbol{\beta}$ is a vector of coefficients for covariates $\boldsymbol{\theta}_{f k y q}^{\prime} \cdot \eta_{f} \zeta_{k}, \gamma_{y^{\prime}}$ and $\delta_{q}$ denote the fixed effects of firm, industry, year, and quarter, respectively. The error term $\varepsilon_{f k y q}$ is assumed independent and identically distributed and uncorrelated with the regressors.

The stand-alone dummy $E C_{f}$ reflects the general business performance of politically connected firms vis-à-vis their nonpolitically connected counterparts. Note, however, that $E C_{f}$ is not separately estimable once we control for firm-level fixed effects $\eta_{f}$ The $D_{1997}$ dummy tells us firms' performance in 1997 and after. The interaction term $D_{1997} \times$ $E C_{f}$ is the variable of interest, which shows performance of politically connected firms in 1997 and after. Should political connections improve firm performance, then we would expect to see that the coefficient on the interaction term displays a positive sign for return on equity, market-to-book ratio, and earnings per share.

Politically connected firms are defined as those having the same politically connected shareholders or directors in both 1997 and 1999. This is to avoid including firms acquired by politically connected individuals after 1996. These firms, connected ex pose, may confound the effects of political connections.

Table 4 shows the ordinary least squares (OLS) regression results. The stand-alone term EC suggests that politically connected firms are associated with better return on equity but worse market-to-book ratio and earnings per share prior to building their political connections. The mixed results provide prima facie evidence that Beijing did not base the allocation of EC membership on firms' economic standing. Both efficient and inefficient firms were able to gain the political connections. The variable of interest, $D_{1997} \times E C_{f}$ is statistically significant in regressions 


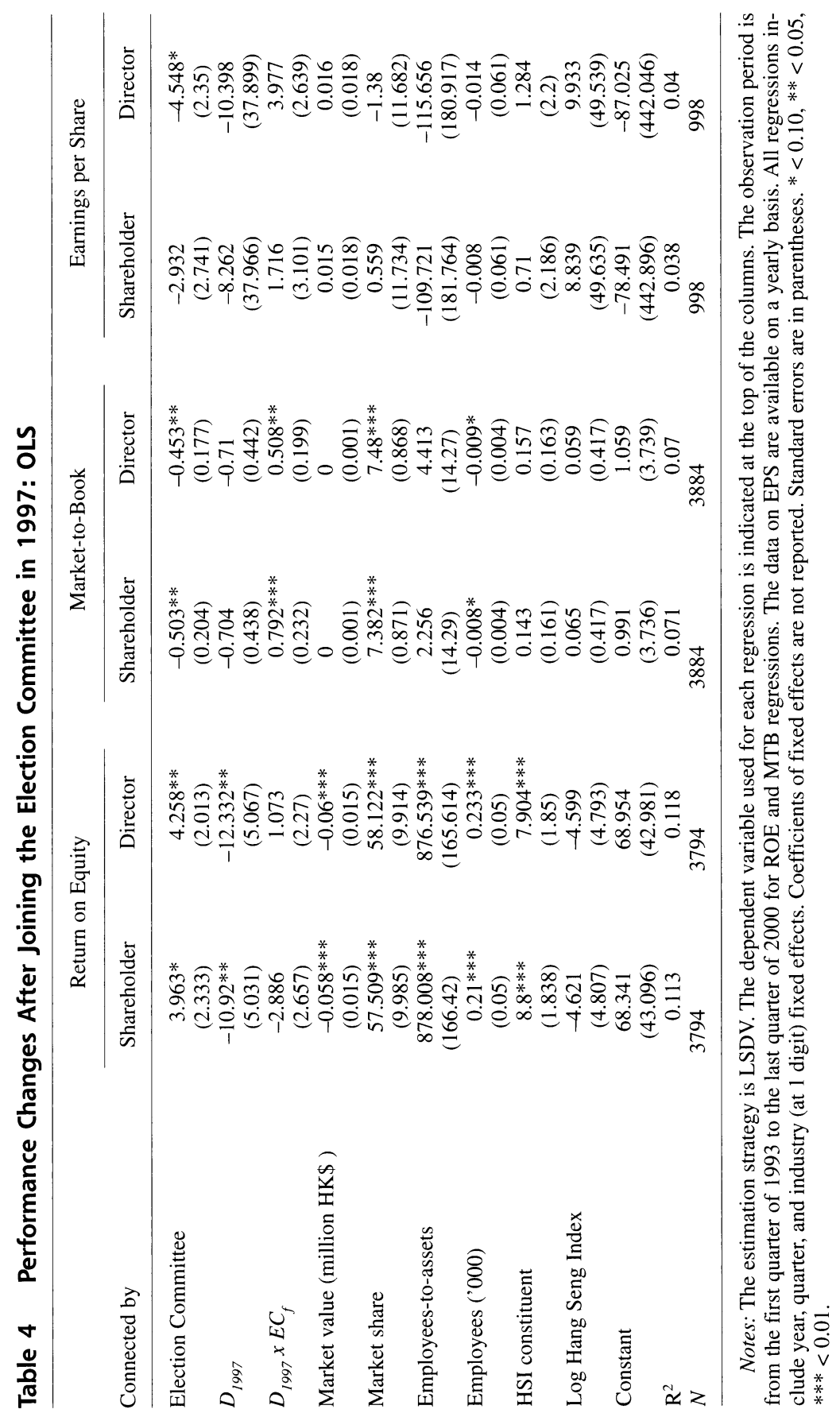


using market-to-book ratio as the dependent variable. The positive sign of the coefficients $(0.792$ for connections through shareholders and 0.508 for connections through directors) indicates that political connections do improve the firms' efficiency. $\mathrm{H} 1$ is partially supported.

Table 5 displays the regression results based on fixed-effects models. Again, I regress the three measures of firm performance on the variable of interests and a set of control variables. The 1997 dummy $\left(D_{1997}\right)$ has significantly negative coefficients across specifications, which is not surprising because Hong Kong suffered from a severe economic downturn between 1997 and 1999 due to the Asian financial crisis.

We again find support for H1. Consider return on equity. The coefficients on $D_{1997} \times E C_{f}$ are 0.572 and 4.864 for connections through shareholders and connections through directors, respectively. The latter coefficient is statistically significant at 1 percent. The positive and significant coefficient indicates that political connections do improve the connected firms' efficiency over time.

A similar efficiency gain is observed in market-to-book ratio. Firms connected to the EC through shareholders experienced, ceteris paribus, a 0.993 point increase in market-to-book ratio after 1996, while firms connected through directors saw a 0.708 point increase. Both coefficients are statistically significant at 1 percent. The magnitude of the coefficients is also of economic significance, considering that standard deviation of the distribution of market-to-book ratio is 2.697.

Finally, the last two columns display results based on the specifications using earnings per share as the dependent variable. The positive sign of the coefficient on $D_{1997} \times E C_{f}$ shows that politically connected firms generally earn more than unconnected firms even before having the political connections. Note, however, the coefficients are not statistically significant.

\section{Political Connections and Firm Performance: Within-EC Variations}

In the previous section, I showed that political connections improve firm performance measured by return on equity and market-to-book ratio. As was mentioned, although the differences-in-differences estimation can deal with reverse causality and unobserved contemporaneous effects on both the dependent and independent variables, it cannot separate the effects of collusion from the signaling effect. We can, however, evaluate the importance of the signaling effect by examining the within-group variation of political connections. 


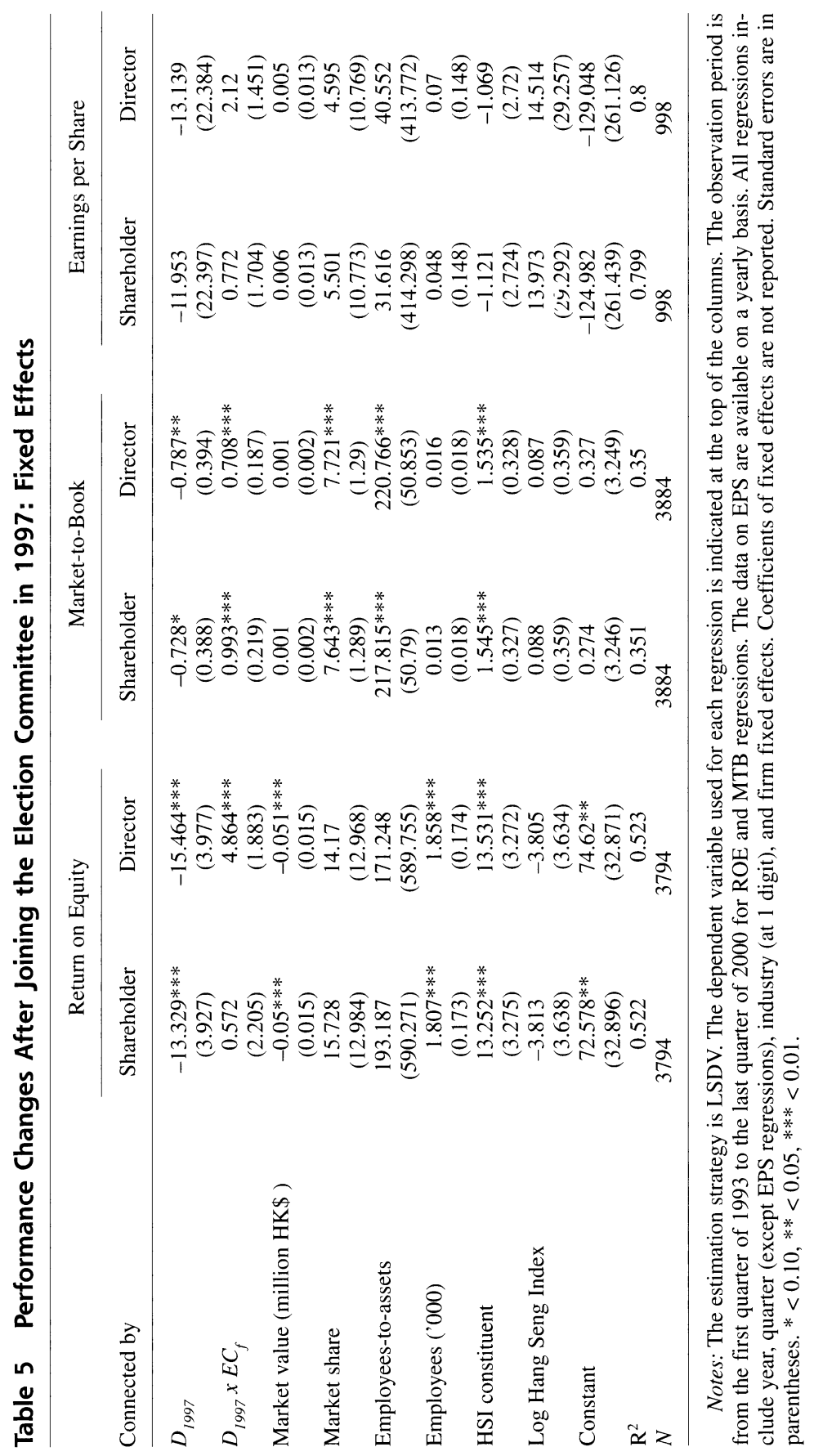


Since the Election Committee is intended to represent a "broad" social spectrum of Hong Kong, each member of the committee carries a specific constituency label. The four constituencies include (1) industrial, commercial, and financial, (2) professional, (3) labor, grassroots, and religion, and (4) political. As can be seen in Figure 1, in the Election Committee, not only the members with a background in the industry have affiliations with listed firms. To see if there exists any within-EC variation in terms of firm performance, the most straightforward way is to examine whether firm performance varies by the EC constituencies.

If EC members coming from nonbusiness constituencies also have firm affiliations, it would be interesting to ask in what kind of firms these members have a stake. In Table 6, I juxtapose EC members' constituencies with the industrial sectors to which their firms belong.

\section{Table 6 Distribution of the 1997 Election Committee's} Constituencies by Industrial Sector

\begin{tabular}{|c|c|c|c|c|c|}
\hline & Political & $\begin{array}{l}\text { Industry, } \\
\text { Commerce, } \\
\text { Finance }\end{array}$ & Professional & $\begin{array}{l}\text { Labor, } \\
\text { Grassroots, } \\
\text { Religion }\end{array}$ & Hybrid \\
\hline & \multicolumn{5}{|c|}{ Shareholders } \\
\hline Basic materials & 0 & 104 & 0 & 0 & 0 \\
\hline Consumer goods & 32 & 278 & 0 & 31 & 0 \\
\hline Consumer services & 31 & 367 & 0 & 0 & 0 \\
\hline Financials & 64 & 451 & 0 & 0 & 0 \\
\hline Health care & 0 & 0 & 0 & 0 & 0 \\
\hline Industrials & 0 & 353 & 0 & 0 & 32 \\
\hline Oil, gas & 0 & 0 & 0 & 0 & 0 \\
\hline Technology & 0 & 144 & 0 & 0 & 0 \\
\hline Telecommunications & 0 & 24 & 0 & 0 & 0 \\
\hline Utilities & 0 & 64 & 0 & 0 & 0 \\
\hline \multirow[t]{2}{*}{ Unknown } & 0 & 16 & 2 & 0 & 0 \\
\hline & \multicolumn{5}{|c|}{ Directors } \\
\hline Basic materials & 155 & 128 & 8 & 0 & 63 \\
\hline Consumer goods & 159 & 382 & 142 & 31 & 150 \\
\hline Consumer services & 88 & 456 & 28 & 0 & 121 \\
\hline Financials & 214 & 744 & 289 & 63 & 326 \\
\hline Health care & 31 & 28 & 0 & 0 & 0 \\
\hline Industrials & 170 & 423 & 211 & 0 & 277 \\
\hline Oil, gas & 0 & 0 & 0 & 0 & 0 \\
\hline Technology & 61 & 142 & 24 & 0 & 23 \\
\hline Telecommunications & 0 & 0 & 0 & 0 & 44 \\
\hline Utilities & 0 & 64 & 0 & 0 & 0 \\
\hline Unknown & 6 & 13 & 14 & 0 & 16 \\
\hline
\end{tabular}

Notes: The unit of observation is firm-year. The data period is 1993-2000. There are four distinct constituencies in the 1997 Election Committee. Some firms have several ECconnected shareholders (directors) who come from different EC constituencies. I created the category Hybrid for such cases. 
The first thing to note in Table 6 is that the members of the Election Committee are more likely to be firms' directors than shareholders. In addition, as expected, the industry, commerce, and finance constituency is overrepresented in the sample of listed firms in the period 1993-2000. Only a few firms have shareholders or directors coming from the labor, grassroots, and religion constituency, which is also not surprising because this constituency by nature should not represent business interests. Interestingly, the members of the political constituency are quite well connected in the business sectors, especially in the financial and industrial sectors. As mentioned in the previous section, this pattern should not be interpreted as evidence that political interests outweighed economic ones. Rather, it reflects that Beijing had used the membership in NPC or CPPCC to co-opt the major Hong Kong business elite long before the formation of the Election Committee.

Switching the perspective from columns to rows, it is easy to notice that the financials is the most politically connected industrial sector, followed by industrials and consumer goods. The financial sector includes major property developers such as Cheung Kong (Holdings) Limited (Stock Code: HK00001) and Sun Hung Kai Properties Limited (Stock Code: HK00016), which have long been perceived to be the most resourceful and politically influential firms in Hong Kong.

To see if the improvement over firm performance varies by EC constituency, see Table 7. In these regression specifications, I replace the EC dummy used in previous regressions with a set of constituency dummies. The sample includes only politically connected firms. Because of a lack of data variation in the shareholders sample, I run the regressions only with the directors sample. Control variables used in Table 5 are included in these regressions.

As can be seen from Table 7, there is no systematic difference across the EC constituencies with respect to return on equity, except that in the OLS regression the hybrid firms (firms that have shareholders or directors coming from different EC constituencies) seem to record a significantly lower return than the baseline group, the political constituency. This statistically significant difference disappears once I control for the firm-level fixed effects. It is therefore unclear if the difference is due to the effects of the constituency or the influences from specific firms. Similarly, we do not observe any systematic difference across constituencies with respect to earnings per share, regardless of which estimation strategy is used.

The only performance measure that shows some systematic differences across constituencies is market-to-book ratio. On the one hand, 
Table 7 Performance Change After Joining the Election Committee in 1997: Within-EC Variations in the Directors Sample

\begin{tabular}{|c|c|c|c|c|c|c|}
\hline \multirow[b]{2}{*}{ Dependent Variable } & \multicolumn{3}{|c|}{ OLS } & \multicolumn{3}{|c|}{ LSDV } \\
\hline & ROE & MTB & EPS & ROE & MTB & EPS \\
\hline$D_{1997} \times E C_{2}$ & $\begin{array}{c}0.652 \\
(3.101)\end{array}$ & $\begin{array}{l}0.837 * * \\
(0.401)\end{array}$ & $\begin{array}{c}0.744 \\
(0.807)\end{array}$ & $\begin{array}{c}-0.075 \\
(2.626)\end{array}$ & $\begin{array}{l}0.719 * * \\
(0.34)\end{array}$ & $\begin{array}{c}0.829 \\
(0.86)\end{array}$ \\
\hline$D_{1997} \times E C_{3}$ & $\begin{array}{l}-2.387 \\
(5.2)\end{array}$ & $\begin{array}{c}0.39 \\
(0.672)\end{array}$ & $\begin{array}{c}-0.348 \\
(1.334)\end{array}$ & $\begin{array}{c}2.003 \\
(4.687)\end{array}$ & $\begin{array}{c}0.906 \\
(0.608)\end{array}$ & $\begin{array}{c}-0.913 \\
(1.505)\end{array}$ \\
\hline$D_{1997} \times E C_{4}$ & $\begin{array}{c}-0.439 \\
(9.657)\end{array}$ & $\begin{array}{c}-2.728^{* *} \\
(1.251)\end{array}$ & $\begin{array}{c}0.69 \\
(2.274)\end{array}$ & $\begin{array}{c}1.996 \\
(7.757)\end{array}$ & $\begin{array}{l}-2.749 * * * \\
(1.006)\end{array}$ & $\begin{array}{c}0.614 \\
(2.318)\end{array}$ \\
\hline$D_{1997} \times E C_{5}$ & $\begin{array}{l}-9.213 * * \\
(3.772)\end{array}$ & $\begin{array}{c}-0.905^{*} \\
(0.488)\end{array}$ & $\begin{array}{c}0.124 \\
(0.971)\end{array}$ & $\begin{array}{c}-1.818 \\
(3.291)\end{array}$ & $\begin{array}{c}-0.108 \\
(0.426)\end{array}$ & $\begin{array}{c}0.408 \\
(1.046)\end{array}$ \\
\hline Industrials & $\begin{array}{l}10.724 * * * \\
(2.268)\end{array}$ & $\begin{array}{c}-0.538^{*} \\
(0.292)\end{array}$ & $\begin{array}{c}0.846 \\
(0.574)\end{array}$ & $\begin{array}{c}0.404 \\
(6.588)\end{array}$ & $\begin{array}{c}1.203 \\
(0.855)\end{array}$ & $\begin{array}{c}0.187 \\
(2.078)\end{array}$ \\
\hline Consumer goods & $\begin{array}{l}9.663 * * * \\
(2.102)\end{array}$ & $\begin{array}{l}0.906 * * * \\
(0.271)\end{array}$ & $\begin{array}{c}0.59 \\
(0.532)\end{array}$ & $\begin{array}{c}-29.736^{* * *} \\
(7.871)\end{array}$ & $\begin{array}{l}-7.332^{* * * *} \\
(1.008)\end{array}$ & $\begin{array}{c}0.382 \\
(2.548)\end{array}$ \\
\hline Health care & $\begin{array}{l}-8.803^{* *} \\
(3.555)\end{array}$ & $\begin{array}{c}-0.389 \\
(0.46)\end{array}$ & $\begin{array}{c}-0.282 \\
(0.9)\end{array}$ & $\begin{array}{c}-35.778^{* * *} \\
(6.019)\end{array}$ & $\begin{array}{l}-2.385^{* * * *} \\
(0.78)\end{array}$ & $\begin{array}{c}-0.343 \\
(1.947)\end{array}$ \\
\hline Consumer services & $\begin{array}{l}12.002^{* * * *} \\
(2.155)\end{array}$ & $\begin{array}{c}0.522 * \\
(0.278)\end{array}$ & $\begin{array}{c}0.549 \\
(0.553)\end{array}$ & $\begin{array}{l}-6.23 \\
(6.238)\end{array}$ & $\begin{array}{l}-1.889^{* *} \\
(0.808)\end{array}$ & $\begin{array}{c}0.553 \\
(1.927)\end{array}$ \\
\hline Telecoms & $\begin{array}{l}-58.313^{* * *} \\
(10.937)\end{array}$ & $\begin{array}{l}-5.382 * * * \\
(1.417)\end{array}$ & $\begin{array}{l}-15.626^{* * *} \\
(2.89)\end{array}$ & $\begin{array}{l}-77.842^{* * *} \\
(17.682)\end{array}$ & $\begin{array}{c}-10.283 * * * \\
(2.294)\end{array}$ & $\begin{array}{c}-4.438 \\
(6.391)\end{array}$ \\
\hline Utilities & $\begin{array}{c}6.161^{*} \\
(3.666)\end{array}$ & $\begin{array}{c}-0.737 \\
(0.474)\end{array}$ & $\begin{array}{c}-1.535 \\
(1.001)\end{array}$ & $\begin{array}{c}-17.854 * * \\
(7.115)\end{array}$ & $\begin{array}{l}-2.002 * * \\
(0.923)\end{array}$ & $\begin{array}{c}-0.274 \\
(2.359)\end{array}$ \\
\hline Financials & $\begin{array}{l}7.133 * * * \\
(2.05)\end{array}$ & $\begin{array}{c}0.408 \\
(0.264)\end{array}$ & $\begin{array}{l}1.203^{* *} \\
(0.526)\end{array}$ & $\begin{array}{c}-9.577 \\
(6.793)\end{array}$ & $\begin{array}{c}-0.687 \\
(0.881)\end{array}$ & $\begin{array}{l}6.328 * * * \\
(2.204)\end{array}$ \\
\hline Technology & $\begin{array}{l}14.939 * * \\
(7.067)\end{array}$ & $\begin{array}{c}0.267 \\
(0.914)\end{array}$ & $\begin{array}{c}1.825 \\
(1.838)\end{array}$ & $\begin{array}{l}-3.74 \\
(7.088)\end{array}$ & $\begin{array}{c}-0.961 \\
(0.919)\end{array}$ & $\begin{array}{c}0.784 \\
(2.347)\end{array}$ \\
\hline Constant & $\begin{array}{c}49.426 \\
(43.214)\end{array}$ & $\begin{array}{c}-0.597 \\
(5.569)\end{array}$ & $\begin{array}{c}14.529 \\
(141.423)\end{array}$ & $\begin{array}{c}57.526^{*} \\
(34.874)\end{array}$ & $\begin{array}{c}0.046 \\
(4.501)\end{array}$ & $\begin{array}{c}-9.408 \\
(156.665)\end{array}$ \\
\hline$R^{2}$ & 0.236 & 0.156 & 0.3 & 0.534 & 0.483 & 0.413 \\
\hline$N$ & 1534 & 1542 & 394 & 1534 & 1542 & 394 \\
\hline
\end{tabular}

Notes: Regressions are based on the directors sample. The observation period is from the first quarter of 1993 to the last quarter of 2000 for ROE and MTB regressions. The data on EPS are available on a yearly basis. $E C_{1}, E C_{2}, E C_{3}$, and $E C_{4}$ are dummy variables denoting, respectively, the political; industry, commerce, and finance; professionals; and labor, grassroots, and religion, the four constituencies of the Election Committee in 1997. $E C_{1}$ is the baseline group. $E C_{5}$ is a dummy for hybrid firms that have directors coming from more than one EC constituency. The industrial dummy for Basic Materials serves as the baseline group. All regressions include control variables used in Table 5. The coefficients of the controls are not reported. Standard errors are in parentheses. $*<0.10, * *<0.05, * * * 0.01$.

firms connected to the industry, commerce, and finance constituency $\left(D_{1997} \times E C_{f}\right)$ benefit systematically more from the political connections than firms associated with the political constituency (the baseline group). The coefficient value is 0.837 in the OLS regression (or 0.719 in the LSDV regression), which is substantively significant because it helps move a firm from the first quintile in the market-to-book distribution up to the third (see Appendix). On the other hand, firms with members coming from the labor, grassroots, and religion constituency underperform their counterparts from the political constituency. The difference, about -2.7 , is of substantive significance. It may reflect the 
nature of the constituency; because this constituency is not intended to represent business interests, what its members obtain or bargain from the government may not be economic rent. The hybrid constituency also underperforms the political constituency with respect to the market-to-book ratio in the OLS regression, though the difference becomes neither substantively nor statistically important once we control for firm-level fixed effects. In sum, H2 is rejected by the MTB results. Additionally, these results suggest that the signaling effect alone cannot explain all the variations identified in the previous section. It is therefore reasonable to suspect that the effects of collusion are at work.

As for industrial sectors, the basic materials industry, the baseline group, significantly outperforms industries including consumer goods, health care, telecommunications, and utilities with respect to return on equity and market-to-book ratio. When it comes to earnings per share, the financial industry stands out. This industry records HK $\$ 6.328$ more earnings per share than the basic materials industry. The value is substantively important because it can move a firm from the first quintile in the distribution of earnings per share up three quintiles (see Appendix).

\section{Getting Political Connections}

As discussed in previous sections, there is no consensus on the origin of firms' political connections. Some argue that successful firms are more likely to build such connections (the "success-driven" hypothesis). However, some find that firms seek to build political connections precisely because they run into trouble (the "failure-driven" hypothesis).

If the first view is correct, we should expect to see that bigger and more powerful firms, such as those that have cornered a market or have employed many workers, are more likely to gain a seat on the Election Committee. If the second view is correct, then we should expect to see that underperforming firms or those that have a heavy debt burden are more likely to become politically connected.

Using firms' membership on the EC, or the lack thereof, as the dependent variable, I apply logistic regressions to analyze the causes of political connections. The specification is displayed below:

$$
\begin{aligned}
\ln \left(\frac{p_{f k}}{1-p_{f k}}\right)= & \alpha+\beta_{1} \text { Market Value }+\beta_{2} \text { Market Share }+\beta_{3} \text { Leverage } \\
& +\beta_{4} \text { Growth of Market Value }+\beta_{5} \text { HSI Constituent }+ \\
& \beta_{6} \text { Employees }+\zeta_{k}+\varepsilon_{f k}
\end{aligned}
$$


where $P_{f k}$ denotes the probability of getting a seat on the Election Committee for firm $f$ in industry $k . \alpha$ is a constant and $\beta_{l}$ to $\beta_{6}$ are coefficients on a set of covariates. $\zeta_{k}$ represents an industry-level fixed effect. The error term $\varepsilon_{f k}$ is assumed i.i.d. and uncorrelated with the regressors.

Table 8 displays the results of logit regressions that regress Election Committee's membership on a set of covariates used to represent firms' characteristics.

The data seem to offer no compelling support for either the successdriven or the failure-driven hypotheses. Market value, which is intended to measure the economic importance of a company, has little predictive value of EC membership (except in column 1D). A closely related concept is market share within an industry. The larger the market share, the more powerful the firm should be. Again, there is no statistically significant relationship between a firm's market share and the odds of getting a seat on the Election Committee (except in column 3S).

Nor does leverage ${ }^{25}$ have any predictable influences on EC membership. What is interesting, though, is that firms with a relatively heavier debt burden were more likely to join the Election Committee in 1997. In 2000, the pattern reversed. Note, however, no coefficient on leverage was statistically significant.

The variable growth rate of market value (3-year average) is intended to capture the growth rate of a company. If the growth rate of market value reflects a firm's potential, then according to the successdriven hypothesis we should expect to see that fast-growing firms are more likely to join the Election Committee. It turns out that the opposite is true. In particular, on the 2000 Election Committee, the coefficient on growth rate of market value is statistically significant in two specifications (3D and 4D), indicating that fast-growing companies are less likely to have directors serving on the Election Committee. My conjecture is that Beijing was not intentionally discriminating against these promising firms. Rather, firms that grow fast tend to be young, implying that they are less visible than well-established firms that have been around for a long time. These young firms might have failed to capture Beijing's attention when the latter selected its co-optation targets.

The only variable that is consistent with the expectation of the "success-driven" hypothesis is HSI constituent. Being a constituent stock in the Hang Seng Index increases a firm's likelihood of getting a seat on the Election Committee. The coefficient on HSI constituent is statistically significant in columns $2 \mathrm{D}, 3 \mathrm{D}$, and $4 \mathrm{D}$, which suggests that directors of HSI firms are more likely to sit on the Election Committee than shareholders. It is unclear, however, whether these HSI firms were 


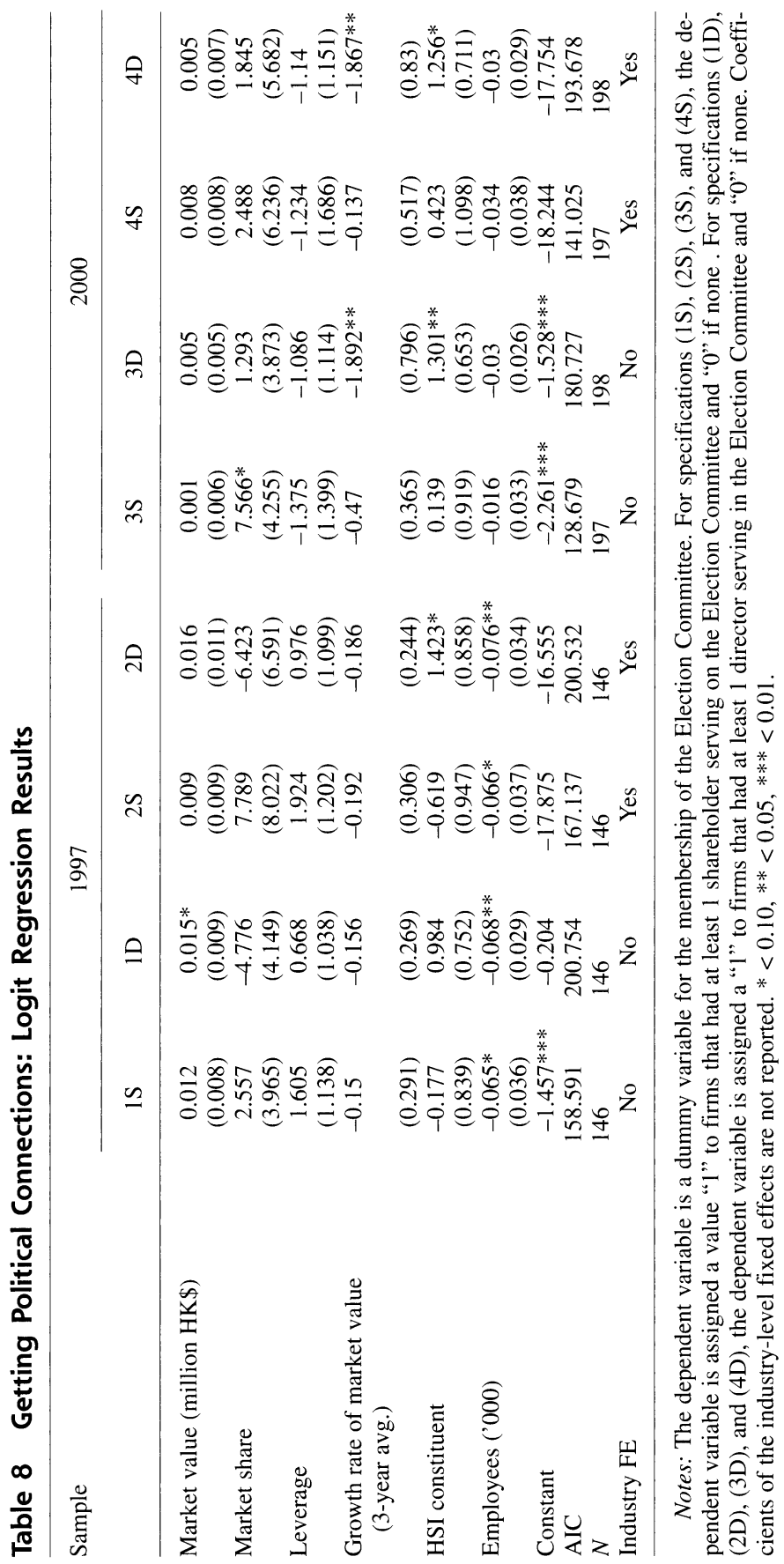


so powerful that they "captured" the seats on the Election Committee or that they were sufficiently visible to draw Beijing's attention when it was selecting its co-optation targets. ${ }^{26}$

The variable employees reveals an interesting pattern that has not been previously considered. The success-driven hypothesis would predict that the more workers a firm employs the greater the bargaining power the firm has over the government. ${ }^{27}$ Contrary to this prediction, the coefficient on the number of employees is negative. It is also statistically significant with respect to the Election Committee formed in 1997.

The coefficient is also of substantive significance. An additional 1,000 workers hired lower a firm's chance of gaining a seat on the Election Committee by 6 to 7 percent. ${ }^{28}$ Note, however, that the effect of employee number on the likelihood of gaining an EC seat is not linear. Figure 2 shows this effect by industry.

Figure 2 Predicted Effects of Employee Number on EC Connections
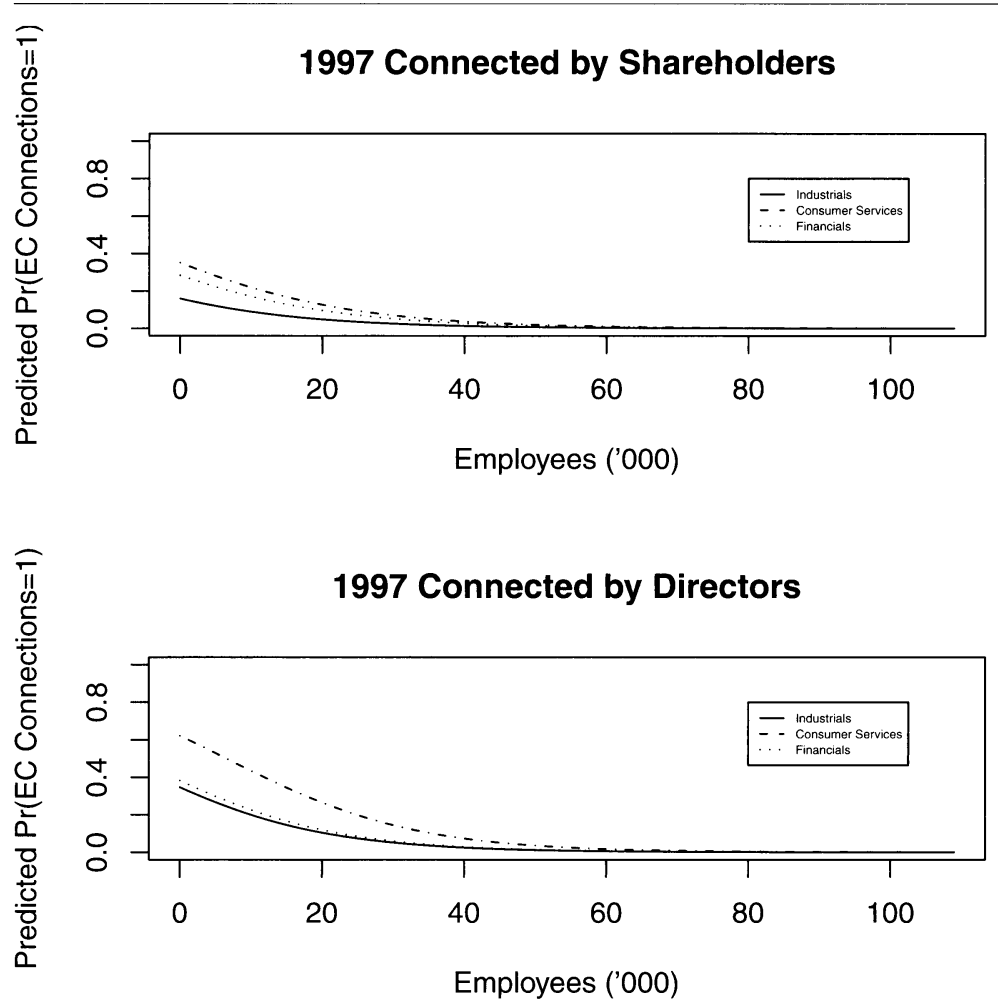
For ease of visual display, I include only the three most politically connected industries (see Table 6): industrials (Industry Code: 2000), consumer services (Industry Code: 5000), and financials (Industry Code: 8000 ). As can be seen from Figure 2, the probability of getting EC connections through either shareholders or directors declines in employee number. But the rate of decline drops precipitously after the number of employees reaches 40,000. At high levels of employees (over 50,000), the marginal effect of an additional unit increase in employee number is insignificant. In addition, getting politically connected through directors is in general easier than through shareholders. Finally, the rate of decline is higher for the financials than for consumer services and industrials.

How do we make sense of this result? The failure-driven hypothesis provides little guide because firms that employ fewer people are not necessarily incompetent. The co-optation explanation again seems to offer a more convincing answer. Bruce Bueno de Mesquita and colleagues (2003) argue in their "selectorate theory" that when the size of the ruling coalition is small, individual members of the coalition receive more private benefits from the incumbent leaders. Inferring from their logic, it should be easier for Beijing to buy off firms with fewer workers than those with many because the private benefits resulting from the co-optation are shared by fewer people. ${ }^{29}$

To summarize, in this section, I find no evidence to support $\mathrm{H} 4$, while the support for $\mathrm{H} 3$ is weak; only one variable, HSI constituent, shows some predictive value of EC membership. The negative coefficient on employee numbers suggests that the formation of the political connections was not necessarily driven by the demand side alone. When there is a need for the government to co-opt the economic elite, it may select its co-optation targets based on some cost-benefit analysis. For instance, it may be more cost-effective to co-opt firms employing fewer workers than those employing many. ${ }^{30}$

\section{Political Connections and Firm Performance: Robustness Checks}

Thus far, I classify political connections by either those secured by substantial shareholders or those secured by directors. There should be some overlap between these two categories because in some companies substantial shareholders also sit on the board of directors. It would be interesting to see if the reported effects of political connections are peculiar to a particular type of connection. I create new variables that 
identify connections through shareholders only, connections through directors only, and connections through both shareholders and directors. In addition, to check if the regression results are sensitive to the count measure of political connections, as is used in Table 5, I test with a dichotomous variable for political connections. ${ }^{31}$

The results of the robustness checks are consistent with Table $5 .{ }^{32}$ The impacts are mostly positive; firms improve their efficiency, as measured by their return on equity and market-to-book ratio after building the political connections through their directors, shareholders, or both. The evidence that political connections have effects on earnings per share is relatively weak. Only when we adopt a dichotomous measure of political connections through both shareholders and directors can we observe a statistically significant, positive coefficient. Overall, the results of the robustness checks suggest that the impacts of political connections on firm performance are not sensitive to how the variable of interest is coded and how the connection is classified.

\section{Discussion}

My aim here is to study the government-business relationship in Hong Kong. In particular, it is the first attempt to test the popular perception of "collusion between government and business." Many who study Hong Kong politics observe that the business elite in Hong Kong offers political support to Beijing in exchange for economic rent. Although anecdotal accounts abound, there has been no systematic empirical investigation into the problem.

To test the collusion hypothesis, I examine firms listed on the Hong Kong Stock Exchange. I find that many of these firms have directors or major shareholders serving on the Election Committee, the political institution that elects the city's chief executive. I regress firm performance, measured by return on equity, market-to-book ratio, and earnings per share, on EC membership. Consistent with the collusion hypothesis, the results show that the political connection yields positive economic payoffs; firms experienced an improvement in return on equity and market-to-book ratio after joining the Election Committee. The improvement in firm performance is unlikely due to unobserved confounding factors such as firms' inherent ability because I use the differences-in-differences estimation strategy to tackle such causal threats. Considering that Hong Kong has been frequently touted for its 
clean government and free-market economy, one should expect that firm performance should be determined by market forces, as opposed to politics. As such, the systematic patterns identified in this study are particularly revealing.

Although the differences-in-differences estimation strategy aptly deals with the threats of unobserved and contemporaneous factors and reverse causality, we cannot separate the effects of collusion from the signaling effect given by the political connections. I evaluate the extent to which the signaling effect drives the observed patterns by examining within-group variations of politically connected firms. The empirical results show that EC firms that come from the business constituency have significantly higher market-to-book ratios, whereas those that come from the labor, grassroots, and religion constituency tend to score lower on MTB. If the signaling effect drives all the results, we should expect that all EC-connected firms should benefit more or less equally by such an effect, regardless of their constituency affiliation. The within-group variation thus suggests that there is something more than the signaling effect that is at work. One possibility is that what EC-connected individuals demand from the government varies by constituency. EC members coming from the business constituency use their political connections to extract business-related private benefits, while EC members from other constituencies aim for other kinds of particularistic transfers.

There is an additional reason why the signaling effect alone cannot explain all the empirical variations identified by the differences-indifferences estimation. As was mentioned, Beijing had co-opted many business elites into various political bodies, such as the Basic Law Drafting Committee, the Preparatory Committee, and provincial people's congresses, long before the formation of the Election Committee. These earlier ties with Beijing were already a signal that these firms were or would be part of the ruling coalition. In other words, the signaling effect should be reflected in firm performance long before 1997. But we still observe statistically significant positive improvement in firm performance for EC-connected firms after 1997. This suggests that the signaling effect may not be able to account for all the variations.

Finally, it is important to note the inherent limitation of the empirical method used in this study. I set out to test the claim of collusion between government and business. The concept of collusion, as is commonly understood in Hong Kong and elsewhere, involves clan- 
destine and wrongful exchanges between the parties involved. The empirical setup of this paper is, therefore, not the best approach to testing such collusion, because I examine the effects of publicly observable political connections on firm performance measured by some financial quantities that are also publicly available. Presumably, these financial quantities cannot capture all the particularistic interests that all the politically connected firms obtain from the government through secret "collusion." That said, this limitation can also be interpreted as a stringent test on the collusion hypothesis. If the collusion involves secret exchanges that are intended to escape public surveillance, then it is less likely to discover the evidence of the collusion from publicly accessible data. When we do find such evidence from publicly observable data, however, we may reasonably believe that the actual extent of the collusion is larger than what is reflected in the available data.

Apart from testing the collusion hypothesis, I also analyze what makes firms politically connected in the first place. I test two common hypotheses regarding the origin of political connections. I find no evidence to support the failure-driven hypothesis, while the support for the success-driven hypothesis is weak. Interestingly, I find that the number of employees employed by a firm has the most significant predictive value of EC membership; firms employing fewer workers are more likely to become members of the Election Committee. The co-optation hypothesis seems to offer a better explanation of this result: Beijing may find it more cost-effective to buy off firms with fewer workers than those with many. In other words, the political connections analyzed here better serve the interests of the supply side (Beijing) than those of the demand side (firms).

Stan Hok-Wui Wong is assistant professor in the Department of Government and Public Administration at the Chinese University of Hong Kong. His research interests include authoritarian politics and comparative political economy, with a focus on East Asia. He received his $\mathrm{PhD}$ in political science from the University of California-Los Angeles in 2008.

\section{Notes}

I am grateful to Jeeyang Baum, Barbara Geddes, Stephan Haggard, Ngok Ma, Wooyeal Paik, Henry Tang, Vivian Zhan, and the anonymous reviewers for 


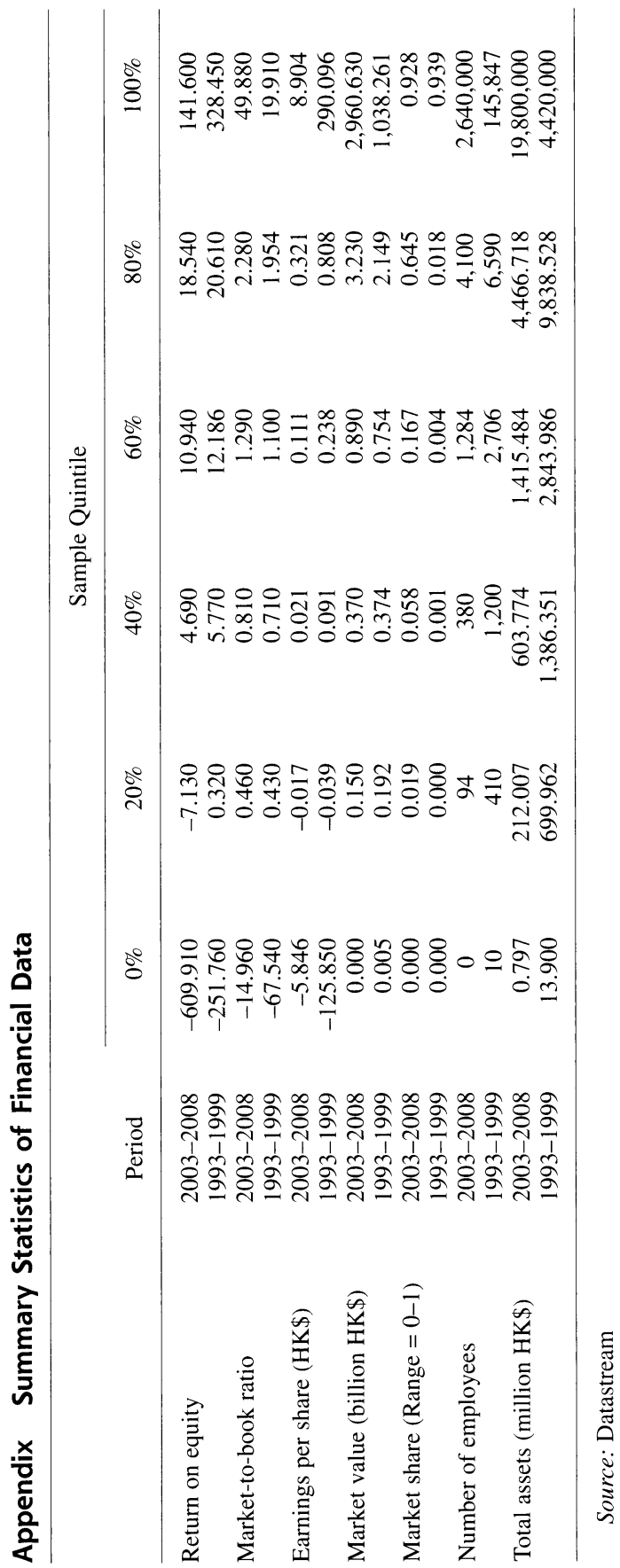


their helpful comments and suggestions. I thank Ivy Ip, Ko Wing Chun, and Christoph Steinhardt for excellent research assistance. I am responsible for all remaining errors.

1. For instance, on the election day of the new Legislative Council in 2008, the headline of Apple Daily, a local newspaper widely known for its prodemocracy stance, read, "No Cronyism, No Collusion Between Government and Business, No Power Abuse by the Government, No Powerful ProGovernment Parties: Cast Your Vote" (Apple Daily, September 7, 2008, p. A1).

2. For example, some view the Tung Chee-hwa administration's decision to grant the development project of an IT industrial park (the "Cyberport") to Li Ka-shing's son in 1999 and to allow Li's company to acquire a piece of land in the New Territories at a cheap price in 1998 as evidence of collusion between the government and big businesses (Lo 2001, 151-152).

3. The official name of the first Election Committee is the Selection Committee of the Hong Kong Special Administrative Region. To avoid confusion, I use "the first Election Committee" to denote the Selection Committee in this article.

4. Hong Kong's ranking in Transparency International's 2008 Corruption Perceptions Index was 12 out of some 180 countries.

5. The aforementioned data come from the Hong Kong government's Census and Statistics Department, National Income and Balance of Payments statistics.

6. This is written in the Basic Law. Article 5 stipulates that "the socialist system and policies shall not be practised in the Hong Kong Special Administrative Region, and the previous capitalist system and way of life shall remain unchanged for 50 years."

7. Zhao (1998) points out that national unity and territorial integrity were the central theme of the Chinese government's patriotic education campaign in the 1990s.

8. To become a chief executive, a candidate must first be elected by the Election Committee and then obtain Beijing's approval.

9. Holliday, Ma, and Yep (2002, p. 459) point out that 77 out of the 800 EC seats go to Hong Kong's delegates to the PRC's National People's Congress and the Chinese People's Political Consultative Conference, while an additional 150 seats are controlled by local organizations under direct PRC guidance, such as some pro-Beijing labor unions.

10. The geographical constituency of the LegCo is popularly elected.

11. Although the exact mechanism that Beijing uses to influence the election of the members of the Election Committee remains opaque, some information can be obtained by examining other elections through which Beijing chooses local representatives to national offices. Lo $(2008,195-196)$ provides an interesting case study of the election of the Hong Kong deputies to the National People's Congress. According to Lo, members of the Election Conference that elects the Hong Kong deputies receive from confidants of Beijing three lists representing three different sectors. Members are encouraged to cast their ballots for a certain combination of the lists. 
12. This is not to deny the possibility that the co-opted business elite has received private spoils from Beijing in addition to the more indirect benefits channeled through improved firm performance.

13. This anecdote explains why I find it more appropriate to focus on the interaction between Beijing and the business elite, as opposed to the interaction between the Hong Kong government and the elite, when discussing the perceived collusion. The role of the Hong Kong government, or its chief executive, is rather passive compared to Beijing or the business elite. After all, the election of the chief executive is completely controlled by the Election Committee and Beijing.

14. For each company, I rely on their financial data reported on January 17, April 17, July 17, and October 17 , or on the closest date on which data are available. I picked day 17 at random.

15. A company is defined to be a red-chip company if it has at least 30 percent of its shares held by mainland China entities or if there is a strong influential presence of mainland individuals on the board of directors. Red-chip companies are usually state-owned enterprises or companies controlled by provincial or municipal authorities. Examples include China Mobile Limited (Stock Code: HK00941), CNOOC Limited (Stock Code: HK00883), and Guangdong Investment Limited (Stock Code: HK00270).

16. The official website of the Electoral Affairs Commission is www .eac.gov.hk/ (accessed January 24, 2010).

17. The data of substantial shareholders in a given year are based on the last reported share transaction. For instance, if Shareholder S owns 10 percent of Company C's shares in January, sells them all in February, and buys them back in March, then Shareholder $\mathrm{S}$ is qualified as a substantial shareholder (because he owns 10 percent after the last transaction) of Company $\mathrm{C}$ in that year, given that there is no more change in his share volume for the rest of the year. Note, however, such a drastic change is rare in reality because substantial shareholders, by nature, tend to maintain lasting and stable ownership of a company.

18. Claessens, Djankov, and Lang (2000) show that cross-holdings are common in East Asia. They argue that major shareholders use cross-holdings to improve their control over the firms.

19. For instance, Li Ning, a famous veteran Chinese gymnast who headed a sport company named after him (Stock Code: HK02331), shared exactly the same Chinese and English names as the son-in-law of a Hong Kong business tycoon, Lee Shau Kee. While the son-in-law has been a member of the Election Committee, the Olympic gold-medalist has never been.

20. For the complete legal regulations on disclosure of interests, see Part XV of the Securities and Futures Ordinance (Cap. 571). An outline of the regulations can be found on the Securities and Futures Commission's website at www.sfc.hk/sfc/html/EN/legislation/securities/partxv/partxv.html (accessed May 5, 2009).

21. Li, Meng, and Zhang $(2006,560)$ point out that membership in NPC or CPPCC is particularly advantageous to private entrepreneurs because it 
gives them not only a certain degree of political power, but also formal and informal ties with important government officials.

22. See, for example, Faccio (2006).

23. A key feature of panel data is that they have a large number of crosssectional units (N) and a small number of observed time periods (T). This is different from Time-Series Cross-Sectional (TSCS) data, where T tends to be greater than N. For TSCS data, standard errors should be corrected for panels, as recommended by Beck and Katz (1995). However, for panel data, the LSDV approach can yield consistent estimates (Johnston and DiNardo 1997). My dataset assumes a panel structure because it contains hundreds of firms observed up to thirty-two quarters at maximum.

24. To be precise, the membership of the first Election Committee was publicly announced in early November 1996.

25. Leverage is defined as long-term debt/total capital. The higher the leverage, the greater the investment risk a company bears.

26. To be eligible for admission into the HSI, a firm has to meet certain criteria regarding its market value, turnover, and listing time. For details, see www.hsi.com.hk.

27. For instance, the government may want the workers' electoral votes.

28. For example, from 2D, the coefficient on Employees is -0.076 . We can interpret this as an odd ratio between getting a seat and not getting a seat by taking the exponential of the coefficient: exp $(-0.076)=0.927$. That is, a unit increase in Employee (1,000 more workers) results in a drop of the odd ratio to 0.927 .

29. I thank a reviewer for bringing up this point.

30. To check if the results are sensitive to different estimation strategies and different measures of political connections, I rerun the above specifications using probit and poisson regressions. In the poisson regressions, the dependent variable is a count variable measuring the number of EC-connected shareholders (directors) a firm had in 1997. The results, which are available from the author upon request, are consistent with those displayed in Table 6 . The coefficients on the number of employees variable are negative and statistically significant across different specifications, except for political connections through shareholders estimated by poisson regressions.

31. A firm is assigned a value of " 1 " when it has one or more shareholders or directors serving on the Election Committee, and " 0 " if not.

32. The results are available from the author upon request.

\section{References}

Agrawal, Anup, and Charles R. Knoeber. 2001. "Do Some Outside Directors Play a Political Role?" Journal of Law and Economics 44, 1: 179-198.

Beck, Nathaniel, and Jonathan N. Katz. 1995. "What to Do (and Not to Do) with Time-Series Cross-Section Data." American Political Science Review 89, 3: 634-647. 
Bueno de Mesquita, Bruce, Alastair Smith, Randolph M. Siverson, and James D. Morrow. 2003. The Logic of Political Survival. Cambridge: MIT Press. Claessens, Stijin, Simeon Djankov, and Larry H. P. Lang. 2000. "The Separation of Ownership and Control in East Asian Corporations." Journal of Financial Economics 58, 1-2: 81-112.

Faccio, Mara. 2006. "Political Connected Firms." American Economic Review 96, 1: 369-386.

Fama, Eugene F., and Kenneth R. French. 1995. "Size and Book-to-Market Factors in Earnings and Returns." Journal of Finance 50, 1: 131-155.

Fan, Joseph P. H., T. J. Wong, and Tianyu Zhang. 2007. "Politically Connected CEOs, Corporate Governance, and Post IPO Performance of China's Newly Partially Privatized Firms." Journal of Financial Economics 84, 2: 330-357.

Ferguson, Thomas, and Hans-Joachim Voth. 2008. "Betting on Hitler: The Value of Political Connections in Nazi Germany." Quarterly Journal of Economics 123, 1: 101-137.

Fisman, Raymond. 2001. "Estimating the Value of Political Connections." American Economic Review 91, 4: 1095-1102.

Gandhi, Jennifer, and Adam Przeworski. 2007. "Authoritarian Institutions and the Survival of Autocrats." Comparative Political Studies 40, 11: 1279-1301.

Geddes, Barbara. 1999. "What Do We Know About Democratization After Twenty Years?" Annual Review of Political Science 2, 1: 115-144.

Goldman, Eitan, Jorg Rocholl, and Jongil So. 2009. "Do Politically Connected Boards Affect Firm Value?" Review of Financial Studies 22, 6: 2331-2360.

Goodstadt, Leo F. 2005. Uneasy Partners: The Conflict Between Public Interest and Private Profit in Hong Kong. Hong Kong: Hong Kong University Press.

Holliday, Ian, Ma Ngok, and Ray Yep. 2002. "A High Degree of Autonomy? Hong Kong Special Administrative Region, 1997-2002.” Political Quarterly 73, 4: 455-464.

- 2004. "After 1997: The Dialectics of Hong Kong Dependence." Journal of Contemporary Asia 34, 2: 254-271.

Johnson, Simon, and Todd Mitton. 2003. "Cronyism and Capital Controls: Evidence from Malaysia.” Journal of Financial Economics 67, 2: 351-382.

Johnston, Jack, and John DiNardo. 1997. Econometric Methods. Singapore: McGraw-Hill.

Khwaja, Asim Ijaz, and Atif Mian. 2005. "Do Lenders Favor Politically Connected Firms? Rent Provision in an Emerging Financial Market." Quarterly Journal of Economics 120, 4: 1371-1411.

King, Ambrose Yeo-chi. 1973. "The Administrative Absorption of Politics in Hong Kong, with Special Emphasis on the City District Officer Scheme." Social Research Centre. Hong Kong: Chinese University of Hong Kong.

Kuan, Hsin-chi. 1991. "Power Dependence and Democratic Transition: The Case of Hong Kong." China Quarterly 128, 4: 774-793. 
Li, Hongbin, Meng Lingsheng, and Junsen Zhang. 2006. "Why Do Entrepreneurs Enter Politics? Evidence from China." Economy Inquiry 44, 3: 559-578.

Li, Hongbin, Pak Wai Liu, Junsen Zhang, and Ning Ma. 2007. "Economic Returns to Communist Party Membership: Evidence from Urban Chinese Twins." The Economic Journal 117: 1504-1520.

Li, Pang-kwong. 2007. "The Executive." In Contemporary Hong Kong Politics: Governance in the Post-1997 Era, ed. Lam Wai-man, Percy Luentim Lui, Wilson Wong, and Ian Holliday, 23-37. Hong Kong: Hong Kong University Press.

Lo, Sonny Shiu-Hing. 2001. Governing Hong Kong: Legitimacy, Communication, and Political Decay. New York: Nova Science Publishers.

- 2008. The Dynamics of Beijing-Hong Kong Relations: A Model for Taiwan? Hong Kong: Hong Kong University Press.

Loh, Christine. 2006. Functional Constituencies: A Unique Feature of the Hong Kong Legislative Council. Hong Kong: Hong Kong University Press.

Magaloni, Beatriz. 2008. "Credible Power-Sharing and the Longevity of Authoritarian Rule." Comparative Political Studies 31, 4-5: 715-741.

Pepper, Suzanne. 2000. "Elections, Political Change, and Basic Law Government: The Hong Kong System in Search of a Political Form." China Quarterly 162: 410-438.

Posner, Richard A. 1974. "Theories of Economic Regulation.” Bell Journal of Economics and Management Science 5, 2: 335-358.

Scott, Ian. 2000. "The Disarticulation of Hong Kong's Post-Handover Political System." China Journal 43, 1: 29-53.

Shleifer, Andrei, and Robert W. Vishny. 1993. "Corruption." Quarterly Journal of Economics 108, 3: 599-617.

- 2002. The Grabbing Hand: Government Pathologies and Their Cures. Cambridge: Harvard University Press.

So, Alvin Y. 1999. Hong Kong's Embattled Democracy: A Societal Analysis. Baltimore: Johns Hopkins University Press.

Stigler, George J. 1971. "The Theory of Economic Regulation." Bell Journal of Economics and Management Science 2, 1: 3-21.

Treisman, Daniel. 2000. "The Causes of Corruption: A Cross-National Study." Journal of Public Economics 76, 3: 399-458.

Yep, Ray. 2007. "The Links with the Mainland." In Contemporary Hong Kong Politics: Governance in the Post-1997 Era, ed. Lam Wai-man, Percy Luen-tim Lui, Wilson Wong, and Ian Holliday, 245-264. Hong Kong: Hong Kong University Press.

Zhao, Suisheng. 1998. "A State-Led Nationalism: The Patriotic Education Campaign in Post-Tiananmen China." Communist and Post-Communist Studies 31, 3: 287-302. 


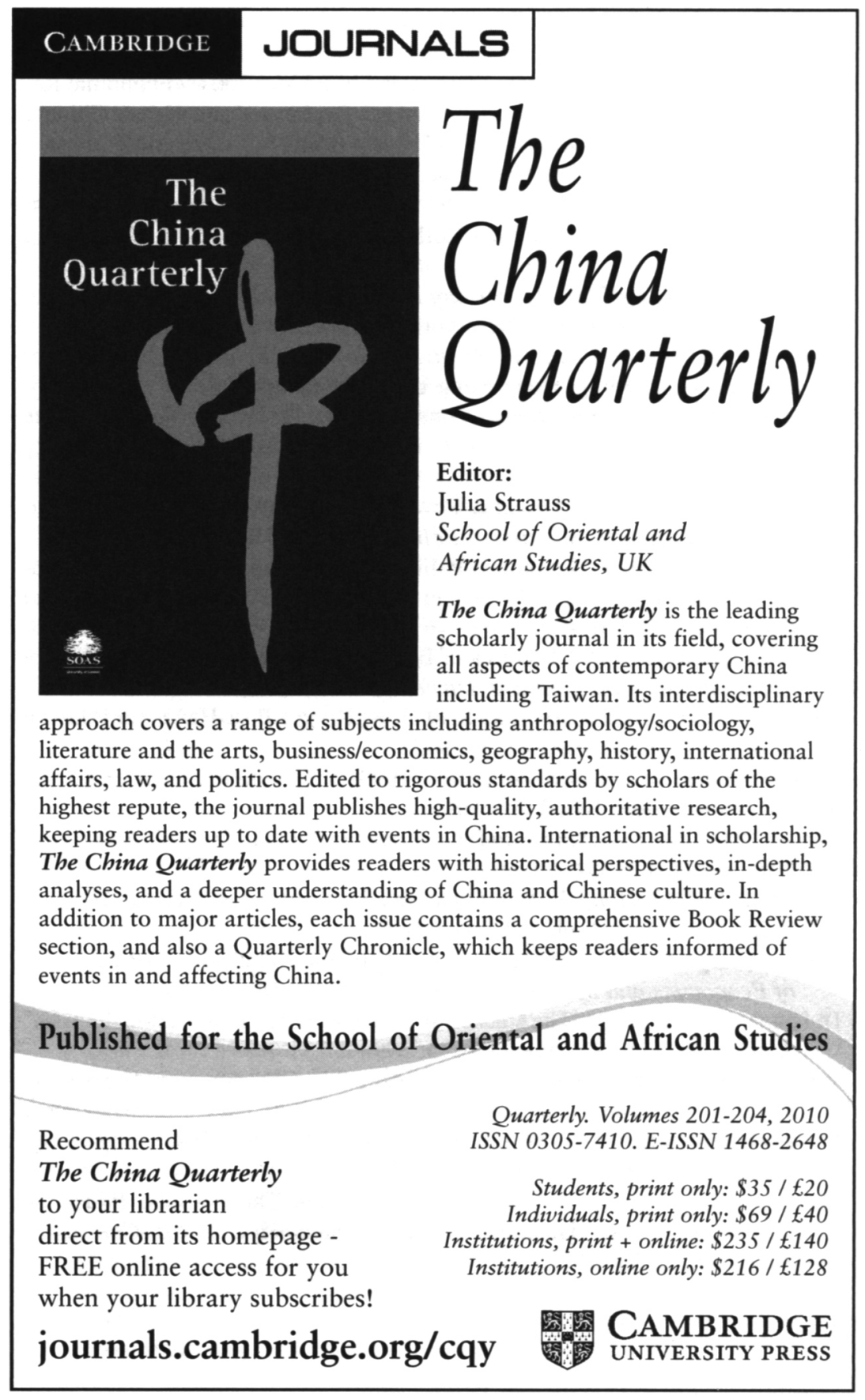

